\title{
Brief Perspectives on the Church and Human Security in Zambia
}

\section{Chammah J. Kaunda Mutale M. Kaunda}

\section{Abstract}

The missio-ecclesia means the church in Zambia is on a divine mission of social responsibility in the context of human security. In keeping with that argument, this article traces the contribution of the church to both human securities and insecurities in Zambia. It argues, from an African perspective, that African religious imaginations affirm the indivisibility of the supernatural and natural reality, without contradicting the humanistic function of the church in its social responsibility. It argues that the church has both adapted some values from the African religious past and is introducing new ideals such as education, health and love that transcends ethnic solidarity to embracing all human beings as expression of the image of God. The article proposes a missio-ecclesia social praxis as appropriate in the church's search to promote human security in the nation.

\section{Introduction}

\section{Calo Cesu (Our Nation)}

You have said that if the devil rises, you will raise a wall, God look at the cries of your children, the enemy has brought fear in Zambia

Small children are being abused and defiled ... they are destroying their chance of getting education.

Yahweh, whenever it gets dark (nightfall), women are afraid to walk/move about.

In the news we hear that a woman is killed somewhere.

How are we to live in our country? 
Zambia cries, women are crying, men are crying,

God our father, help us in sustaining our country.

Zambia is our country.

God our father we come to you, to seek peace from you, our shepherd of peace.

Bring peace to our country Zambia, we cry.

Leaders please govern us in our country ... widows and orphans are on the increase.

Their abode is in the streets and furrows.

Their food is picked from garbage bins and begged for in the streets.

God come and give us rest ... diseases have taken our loved ones.

The world has lost its way ... there are so many tears/ sorrows/cries.

Listen to how the poor are crying out to you saying 'God show yourself'.

Zambia we pray for love, we pray for peace, we pray for justice.

(Calo Cesu Project 2017.)

The song above shows the gravity of the existential challenges and the threat to human security in Zambia, as perceived in this project song. It also demonstrates the enduring social responsibility of the Church in the struggle for human security. Gerrie ter Haar and Stephen Ellis (2006:352) call the incessant presence of religion as one of the 'greatest surprises' of the $21^{\text {st }}$ century. The modernisation process in the western world was closely associated with deep faith in the liberating power of science and technology. The primacy of science and technology was perceived as a basis for theories of modern development which excluded religion as an extraneous and superstitious worldview (Ter Haar \& Ellis 2006). But now, the celebrated Max Weber's (2002:51) essentialist prophecy of 'disenchantment of the world' did not even begin to evolve in Africa before beginning to fall out of favour even within western social scientific thought. In his The Desecularization of the World: Resurgent Religion and World Politics, Peter Berger (1999), renowned sociologist of religion and father of the secularist hypothesis, pleaded guilty to an incorrect scientific observation in the mounting evidence on the resilience 


\section{Chammah J. Kaunda \& Mutale M. Kaunda}

of religion (Westerlund 1996). Berger renounced his former position that the rise of the modern pluralistic worldview would force religion to fold its arms in anguished surrender, and retract in an abyss of nothingness while cursing. Conceding that 'the relation between religion and modernity is rather complicated' Berger (1999:2-3) sees the world 'as furiously religious as it ever was, and in some places more so than ever'. As things stand, religion in Africa, in Zambia in particular, constitutes a socio-political reality shared widely on the continent (Gifford 1998; Ter Haar \& Ellis 2006).

Thus, it is rather interesting to note that much of the studies on human security in Africa have paid little attention to the role of religion (Abass 2010; Picard et al. 2015; Behnassi \& McGlade 2017), perhaps, because of the conflictive role it has played in some parts of the continent, it has been perceived as an obstacle to human security ${ }^{1}$. The need to analyse the relation between religion and human security in Zambia is based on the fact that Christianity has never left the public sphere since Independence. In her article, 'Legitimizing Powers', Marja Hinfelaar (2008: 130) demonstrates that 'One important reason why Christianity never left the public sphere after Independence was the growing authoritarianism of the Zambian political system'. Even though correct, this argument neglects the material legacy of the African historical and religio-cultural past. The intertwinement of religion and state is ingrained within African religio-political imaginations. The western ideals of the separation between religion and state have 'proven more theoretical than actual' (Olupona 2014:2), in most African religio-political imaginations. Thus, to argue as Hinfelaar does, is to bring western assumptions into a completely different worldview, with its own ideals.

This article examines the social responsibility of Christianity in the promotion of a holistic human security in Zambia. In the following paragraphs we first consider how the concept of human security is viewed through the prism of African traditional worldview. This is followed by an examination of the role the church has played in promoting human security in different periods of postcolonial Zambian society. The third section provides some reflections

${ }^{1}$ Many scholars (Katongole 2009; Smith \& Hackett 2012) have paid attention to the role of religion in fuelling conflict in various parts of Africa. However, religion has also played a constructive role as was the case in conflict resolution in South Africa (Shore 2009), and the democratic transition in Zambia (Gifford 1998). 
on the missio-ecclesia, as a critical resource in enhancing human security in Zambia. The notion of missio-ecclesia is used in reference to the church's Godgiven mission of social responsibility in the context of human security.

\section{Thinking about Human Security: An African Turn}

The contemporary idea of human security is a secularist orientation, with an overemphasis on material security. It has been largely defined by western experience with its classic modernist worldview which excludes spiritual security as analytical category for constructing relevant knowledge for promoting holistic human security. Harvey Sindima (1995: 215) has noted that 'according to the African way of life one cannot talk about society without mentioning the role of religion'. The pervasive influence of religion in all spheres of human life is critical in understanding the role religion plays in promoting human security in most African societies. Human security cannot be limited to physical well-being as it requires maintaining an intricate equilibrium between the visible and the invisible world, human beings and nonhuman creation, and within human relationships (Mbiti 1969; Idowu 1973; Sindima 1990; Magesa 1997).

In this world-view, awesome relationships and harmonious interactions are crucial for the security of an individual. Sindima (1990: n.p.) stresses that in most African societies, human security is derivative of 'bondedness', 'the act of sharing and living in communion and communication with each other and with nature'. This is based on understanding that individual security is realised in solidarity with God, other human beings and nonhuman creation. This means that there is a profound interpenetrating union that existd between an individual and the community. This is a primary category that provides the basic framework for understanding human security in an African world-view. Mbiti (1969:109) explains that 'whatever happens to the individual happens to the whole group, and whatever happens to the whole group happens to the individual. The individual can only say: "I am, because we are; and since we are, therefore I am". Eboussi Boulaga (1984: 81) summarises the moral-ethical imperative of responsibility; 'What falls on one, falls on all. In such a relationship, the issue is the re-establishment of community, the re-establishment of the circulation of life, so that life can go on transcending itself, go on bursting the barriers, or the intervals, the nothingness, go on being superabundant'. Hence, in African societies, the 


\section{Chammah J. Kaunda \& Mutale M. Kaunda}

primacy of religion is positioned as part of tis functionality, rather than a mere individual relationship with some supernatural being. Many African people understand that the 'ultimate concern' of religion is human security. The essence of religion for many is directed against threats to human life (Mbiti 1969; Idowu 1973; Booth 1978; Boulaga 1984; Dyrness 1990; Sindima 1990; Magesa 1997; Tembo 2012; Waogaidu 2014). William Dyrness (1990:43) argues that 'the world and life are believed by many African people to reflect a fundamental harmony that religion and ritual are meant to preserve or enhance'. Thus, religion is perceived in humanistic terms, as primarily concerned with human values (Mbiti 1969; Booth 1978). In other words, religion is foundational to the sense of security for many Africans. As Mbiti (1991:15) argues,

... within that religious way of life, they know who they are, how to act in different situations, and how to solve their problems. This does not mean religion has no weaknesses or no false ideas. But as far as it goes, it has supplied the answers to many of the problems of this life even those that may not have been the right answers in every case. Because it provides for them answers and directions in life, people are not willing to abandon it quickly. Otherwise they would feel insecure afterwards ....

This means that religion is central in the realisation of human security within the community of life. It is the people's instrument of hope in their search for security of life against threats to human wholeness (Tembo 2012; Waogaidu 2014). In African systems of thought, religion is also not limited to the supernatural world of spirits, and demons; it has a humanistic function as an ideological instrument for promoting human security. It is this worldview that has stimulated the church's role in advancing human rights, health, education, social equality, democratization, and economic development, as part of the modern world. In other words, the idea of human security could be seen as the secular translation of the religious notion of 'Shalom' or 'Salam' (fullness of peace/ wholeness in Hebrew and Arabic respectively) or 'abundant life' (John 10:10) or 'well-being' (Qur'an 36:58), that are in radical contrast to the more conventional focuses on national security and how a nation preserves its borders and safeguards sovereignty - which too often overlook the security of those within its borders. 
The quest for abundant life/ wholeness is the core concern of most living religious systems of the world (Magesa 1997; Jackson 2005; Cornell 2007). Human security as a state of wholeness in religious terms is an organising principle for many religious beliefs, practices, and spiritual visions. The notion is oriented toward a sense of cosmic order, how life strives in the universe through 'bondedness' (Sindima 1990). It refers to the state of human awesomeness - socially, materially, economically, psychologically, culturally, mentally, spiritually, and politically, where subjective experiences about human rights and 'freedom, self-expression, and human autonomy' (Samson 2012: 151) and values are honoured. It recognises the comprehensive and holistic nature of human beings. The argument here is that spiritual and material securities are indivisible. This means that addressing insecurities arising from a spiritual world is simultaneously addressing material insecurities. In other words, the spiritual security secures material security, and restores cosmological wholeness. The traditional African vision of human security, of wholeness, of unity for both human beings and nonhuman creation is not one of the several options for the mission of the Church. It is an imperative.

\section{Christianity and Human Security in Zambia}

We focus on Christianity because, since its introduction by European missionaries in the 1880 s, its influence is so deeply entrenched, that it virtually dominates all aspects of Zambian life (Tembo 2012:308). Christianity influences and determines moral sensibilities and political imaginations which greatly influence public discourses and defines national identity (Van Klinken 2014). But the Africanness of the Zambian context means that most of the people struggle with spiritual and physical insecurities. It is argued that, while the mainstream Roman Catholic and Protestant Christianities followed very strictly and stuck closely to the mother church canons and doctrines, the lingering spiritual insecurity of Zambian people has attracted Charismatic type of spiritualities (Tembo 2012:320). Indisputably, the history of Christianity in Zambia has sought to promote human security. The missionaries pioneered formal education, vocational skills training, and health care services. The first national leaders in Zambia were educated in mission schools.

For example, the father of the Dr. Kenneth Kaunda, the first president of Zambia, David Kaunda, was a Malawian Presbyterian ordained minister and African pioneer mission-ary to Zambia, with the Church of Scotland to 


\section{Chammah J. Kaunda \& Mutale M. Kaunda}

Zambia. Kaunda grew up in a Christian activist home in which 'The most important book of all was the Bible which the Kaunda children studied every day and in the evenings read out to the family gatherings' (Kaunda 1962:137, also cited in Hall 1964:14). It was this Christian worldview which developed Kaunda's nationalist conviction as an African freedom fighter. He used 'Christianity as an ideological base from which to confront political injustice' (Phiri 2001: 25). After independence, Christianity provided for the new nation the impetus for social cohesion, unity and a sense of belonging for Zambia's seventy-two ethnic groups (Tembo 2012:309). Kaunda accentuated Christian values through the slogan 'One Zambia, One Nation', which he argued was a 'way to show the world that as a Christian nation, God is all powerful in the citizens' family lives' (cited in M'fundisi 2012: 75). Many of these ethnic groups may have been enemies and might have been frequently at war, but Christianity has functioned as a reconciling and unifying factor, by unveiling common shared values within traditional religions such as humaneness, hospitality, love for the enemy, to do to others as you would want them do to you, kindness, justice, peace and love (Tembo 2012:309). Kaunda affirmed 'the church is one of the five special pillars of the nation, along with the press, judiciary, the legislature and the executive (Gifford 1998 194; also cited in Hinfelaar 2009: 194). However, the 'One Zambia, One Nation' slogan was weakened as it was utilised as launching pad for the imposition of 'one party, one leader', which reduced the nation into an authoritarian state (Taylor 2006; Gewald, Hinfelaar \& Macola 2008; Marten \& Kula 2008; Gordon 2012).

Formal education in Zambia is also a legacy of missionary commitments to the educational security of the Zambian people. As Paul Gifford (2015:86) notes, although all denominations have been involved, the Catholic Church is the most heavily committed. Zambian education functions with three types of schools - government schools, grant-aided, and private schools. There are also three levels of schooling, which start with primary schools which run from grade 1 to 7 , followed by the intermediate schools - also known as basic/ secondary schools, from grade 8 to 9 , and in the final stage, high school, from grade 10 to 12 . Gifford (2015:87) observes that,

The Catholic Church in 2004 ran forty-three high schools, thirty-five grant-aided, and eight private schools. It runs thirty-grant-aided basic schools, nine grant-aided special schools (mainly for the handicapped), and two grant-aided colleges as well as two grant-aided 
technical and vocational institutes .... In all, about 15 per cent of the total educational enterprise in Zambia is under the aegis of the Catholic Church.

Indeed, this does not capture the full contribution of the church to educational security in Zambia. For example, in 1975, 60\% of all the students at the University of Zambia (UNZA) had roots in Catholic schools (Carmody 2007; Gifford 2015).

The government of Frederick Chiluba, the second Republican president of Zambia, recognised the significance of the churches in providing education and 'introduced a new Education Act in 1993 which allowed Churchsponsored institutions significantly greater freedom in terms of financing, student enrolment, appointment of staff, and curriculum development' (Carmody 2010:286). Thus, the churches in Zambia have much control over their schools - much more than some other African countries (Gifford 1998:189). This has also contributed to most churches seeking to ground their own school in the country. At the turn of the year 2000, many Christian denominations started to build their own universities. The Roman Catholic Church has established the Zambia Catholic University (ZCU). The Seventh Day Adventist Church has founded Rusangu University (RU). The Evangelical oriented Northrise University (NU) has also been established in Ndola. The churches have continued to struggle against threats to human life through providing quality education even in the remotest areas of the country. Many Pentecostal churches have also started to provide education from nursery school right through to high school, and to establish universities and colleges (M'fundisi 2012). The challenge for many of these schools and universities is that they are classified among mushrooming private schools which tend to accommodate mostly the children of the rich and the powerful, and are being questioned as to what they provide 'besides entry to the often corrupt elites' (Gifford 2015:88).

Health interventions is another key area that the churches have provided in Zambia since the 1880s. Many churches in Zambia, including Pentecostals, have affirmed that evangelisation and social involvement are inseparable. In an effort to become more viable in providing health care, the Catholic and Protestant Churches' health institutions established the Churches Health Association of Zambia (CHAZ) in 1970. The Association is the largest non-governmental health provider in Zambia. It has 151-member health 


\section{Chammah J. Kaunda \& Mutale M. Kaunda}

institutions. The majority of these health institutions are based in rural areas. They comprise 34 Hospitals (including 9 nursing and laboratory technologist Training Schools); 77 Health Centres; and 31 Community-Based Organizations (CBOs). Together, these institutions account for over 50\% of formal healthcare in rural areas and roughly $35 \%$ of healthcare nationally (CHAZ 2013).

Besides being involved with CHAZ, the Zambia Catholic Church has its own Health Department of the Zambia Conference of Catholic Bishops (ZCCB) (formerly, the Zambia Episcopal Conference - ZEC) which was established in 1996 as a coordinating department for effective response to HIV/ AIDS and other health issues. The department functions both as a National Health Institution and deals with Community Home Based Care Programmes. It coordinates activities in 17 Hospitals, 37 Health Centres, 3 Nursing Schools, 10 Hospices and 220 Community Home Based Care programmes. These institutions and programmes are found throughout the 10 Catholic Dioceses of the country. The Health Department also runs Cardinal Adam Memorial Hospital on behalf of the Zambia Episcopal Conference (ZEC 2016).

The struggle against HIV and AIDS has forced some Pentecostals to redefine their understanding of mission and evangelism. They called for a holistic mission. In 1999, through the efforts of German Missionary, Dr. Helmut Reutter of the Gospel Outreach Fellowship, and Bishop Joshua Banda, the senior pastor of Northmead Assembly of God in Lusaka, and the financial support of World Vision Zambia, they established the Expanded Church Response (ECR) to HIV and AIDS (Banda 2013: 43). ECR works with over 150 local churches and faith-based organizations throughout the nation. In addition, ECR has been helping orphans and vulnerable children by offering them education (ECR 2012). Bishop Banda, whose church has a strong social orientation, was the chairman for ECR, and also the National AIDS Council of Zambia at the time of writing.

Through such missional health care praxes, churches in Zambia have become the instruments of hope for human security. Without missional health intervention of the churches, the majority of rural dwellers would have no access to desperately needed healthcare in the nation. President Edgar Lungu in a speech read by Minister of Health Dr. Joseph Kasonde at a Cardinal Adam Memorial Hospital fundraising dinner dance in 2016, acknowledged the role the Church plays in providing health care to the people of Zambia. He affirmed 
that 'the Church will continue to be government's reliable partner in the provision of health care', adding that his government 'was grateful to the Church's $60 \%$ of health service provision in the rural areas of Zambia' (ZEC 2016).

The other key aspect was the churches' role in democratisation of Zambia. The churches became bridges of transition from Kaunda's 27 year one-party-one-man-rule to multiparty democracy in 1991. Scholars have applauded the church's ecumenical resistance against Kaunda's dictatorship as 'genuine ecumenism' (Gifford 1998:188). The introduction of the one-party state was a means to restrict all opposition movements, strengthen the dissident voice of the churches in resisting corruption and injustice, and calling for a multiparty democratic system. In 1972, the three major church bodies, the Evangelical Fellowship of Zambia (EFZ), the Christian Council of Zambia, (CCZ) and the Zambia Conference of Catholic Bishops (ZCCB), launched a politically engineered monthly newspaper, The National Mirror. Besides religious news, the paper offers news and information on a range of politicallyoriented issues on African leadership, economic wellbeing, university student's concerns and grievances, and donors' support or reluctance to lend to Zambia, and so on (Gifford 1998). Another tool was a Catholic Bembalanguage monthly, Icengelo, which had extensive political coverage. It published the first interview with Chiluba who was only vaguely known at that time. Through such publications, the church promoted public dissent against Kaunda's repressive government. The churches would also join together to form the Christian Churches' Monitoring Group which became a major force in the formation of the Zambia Elections Monitoring Coordinating Committee (ZEMEC). This group set to train a grassroots army of observers to observe procedures at every polling station on every Election Day (Gifford 1998:196).

The struggle for democratic security is exemplified in the religious media that came to serve as a platform to air concerns and to lobby the state on a variety of issues at the core of Zambia's civic concerns. The media also strengthened the Church's ecumenical voice (M'fundisi 2012). The three mother bodies have written joint pastoral letters on a number of issues such as mining, gender justice, HIV and AIDS, economic justice, including matters of governance. The churches in Zambia have realised that issues of human security are not only the government's concern but religious concerns as well. The churches have also realised that human security as a multifaceted issue needs a multifaceted response. These many churches across denominations are involved 'in matters concerning the constitution, governance, health, educa- 


\section{Chammah J. Kaunda \& Mutale M. Kaunda}

tion, economic justice, elections, rural and urban development, youth empowerment, agriculture, gender issues, church-state relations, politics and socio-economic justice' (M'fundisi 2012: 3).

The church has also continued to secure spiritual security for most Zambian people. A resilient feeling of spiritual insecurity overwhelms the majority of Zambians. Spiritual insecurity remains a very serious challenge and affects the lives of the vast majority of Zambians (Tembo 2012). Indeed, the present adaptation of spiritual insecurity in contemporary Africa must be regarded as a 'form of cultural modernisation' (Chabal \& Daloz 2006:165). This is perhaps, much more a national challenge than even material insecurity. Achieving material security, higher education, the accumulation of wealth, a high paying job, do not meet the needs associated with the Zambian struggle for spiritual security. The fear of witchcraft and accusations thereof define the existence of the majority of Zambians, including politicians.

In actual fact, some politicians such as Hakainde Hichilema, the President of Zambia's main opposition party, the United Party for National Development (UPND), has been accused of being Freemason, by the Orthodox Bishop, Edward Chomba. The 2016 election campaigns were implicated in ritual killings in Lusaka. In turn UPND President Hichilema accused President Edgar Lungu of inviting sangomas/ bashi ng'anga (traditional doctors/ prophets) from Malawi to help him win the 2016 elections (Lusakatimes.com 2016). The general population in Zambia is entrenched in beliefs that most sicknesses, struggles with formal education, unemployment and many other bad occurrences are related to witchcraft or demonic activities. Thus, while engaged in social ministries, many Pentecostals are aware that they have to also address needs arising from the Zambian spiritual world, though sometimes they also exaggerate them. Allan Anderson (2014: 241) observes that Pentecostals have 'provided places of spiritual security and personal communities for people unsettled by rapid social change'.

Christianity is perceived as presenting the ultimate option against the fear of witchcraft and demonic forces. This is why churches in Zambia have taken public prayers seriously. It has always been utilised as an instrument of spiritual reassurance of God as the Guardian Spirit over the nation. In March 1953 at the Congress Delegates' Conference at Kabwe, the African National Congress called the people for the two days of National Prayer, to ask God to assist Africans in their struggle against the Federation (Kaunda 1962:147). Another critical National Day of Prayer was called in 1991 for a peaceful 
nation, and a peaceful presidential election and democratic transition. The Times of Zambia newspaper had its front-page headed on 10 October 1991 'KK Harbouring Commandos'. There was an allegation by some officials within the Movement for Multiparty Democracy that Dr Kenneth Kaunda was hiding over 100 commandos in Chamba Valley in Lusaka to create a civil war, if he lost the presidential election (Africa Analysis 1991: 98). Though Kaunda rejected such allegations, the masses continued in fear civil war. In addition, some Zambians believed that Kaunda was a wizard, and that he would use witchcraft to win presidential elections. Prominent Pentecostal clergymen, Bishop John Mambo and Bishop Joseph Imakando called for the National Day of Prayer on 27 October 1991, a few days before the elections on 31 October 1991 (Gordon 2012: 194). This call for National Prayer Day was crucial in overcoming spiritual insecurities which included rumours of civil war. Elder Gibstar Makangila of Northmead Assembly of God testifies:

Former President [Kaunda] had so much power ... his army, the intelligence, they would easily have disregarded the election results, but the prayers of the Christians which had gone on before, were too powerful. I believe that the hearts of Kaunda and his people were melted by God. It was not politically possible to remove him and his henchmen at that time, except, it had to be an act of God (cited in Gordon 2012: 194).

Many Christians in Zambia believe that Kaunda was 'defeated only by a miracle' (Gordon 2012: 194). For example, in his article 'Zambia Returns to God', Rev. Ronald Mwape (1991: 5) says that 'Christians consider President Chiluba's victory as an answer to their protracted prayers'. He (1991:5) said:

In the scramble for Zambia, Christians prayed, and Satanists meditated, and prayed, suspended in mid-air. At the end of the day, Christ's forces prevailed against the kingdom of darkness, for it is written: The forces of Hell shall not prevail against the Church.

In the midst of hostile economic struggles, political turmoil and ethnicity, President Edgar Lungu followed the national historical trajectory and called for the National Day of Prayer on $18^{\text {th }}$ October 2015, which he also gazetted as a holiday to be known as a National Day of Prayer, for Thanksgiving and 


\section{Chammah J. Kaunda \& Mutale M. Kaunda}

Reconciliation. This shows the critical role prayer plays in citizens' spiritual security. However, it is increasingly questioned whether the National Day of Prayer truly provides spiritual security, or whether it is used as a political tool to legitimize presidential authority. It is also important to state that many churches are involved in catering for the spiritual needs of their congregants through ritual emphases on healing and miracles, deliverance from demonic bondages, and prayer for spiritual warfare. In recent times, there is a new phenomenon called neo-prophets who are mainly young men, who project themselves as indispensable mediators of spiritual resources with great spiritual power to explain spiritual mysteries, perform extraordinary miracles such as the providing of 'miracle money', 'miracle marriages', 'miracle education', 'miracle jobs', and that they can cure any kind of disease or sickness, such cancer, HIV. They also claim to raise the dead, and have the power to protect their clients from any form of misfortune, especially witchcraft, and that they can explain future events (Kaunda 2016b). The neo-prophets appear to function much in the same way sangomas function in traditional African societies. In other words, because they address Zambian people's spiritual needs and insecurities in 'sangomsised' ways, many people - both Christian and non-Christian - are attracted to them. This phenomenon is essentially seen as sangoma modernisation and Christianisation.

\section{The Church and Human Insecurity in Zambia}

In relation to the aforementioned, the church has also been a source of human insecurity for certain groups of people in Zambia. The church has positioned itself as an anti-sexual minority or homophobic institution. It prohibits public dialogue on sexual matters, harasses and persecutes sexual minorities, as was the case with Zambian human rights activist Paul Kasonkomona (Kaunda 2016). There are numerous examples of homophobic expressions among Zambian clergy across the denominations. For example, Bishop Joe Imakando of the Bread of Life Church International, argues that 'homosexuals and lesbians have no room in society, because Zambia had been declared a Christian nation' (Times of Zambia 2010). Many Evangelical leaning leaders follow this perspective - Bishop Bernard Nwaka of Living Waters Global Churches in Africa; Rev. Pukuta Mwanza, Director of the Evangelical Fellowship of Zambia; Bishop Paul Mususu, the chairperson of the Evangelical Fellowship of Zambia; Bishop Joshua Banda of Northmead 
Assemblies of God; Bishop John Jere of Zambia United Christian Action President; Rev. Conrad Mbewe of Reformed Baptist ${ }^{2}$. Heterosexism is equally shared by mainline Protestants and Roman Catholic religious leaders. The Anglican Bishop of Luapula, Robert Mumbi, for example, claims that 'homosexuality is against the African traditional way of life, and Christian values' (Blog Admin 2010). In his statement, 'Homosexuality - what the Bible teaches', the Roman Catholic, Zambia Episcopal Conference (ZEC) Communication Secretary and Spokesperson, Father Paul Samasumo writes, 'The Catholic Church's constant and firm teaching on homosexual acts is unequivocal. Homosexual acts are seriously wrong and sinful' (The Times of Zambia 2011). The churches in Zambia in whatever traditional form, are united as one voice, in rejecting the rights of the sexual minorities (Kaunda 2016).

\section{Human Security as Missio-Ecclesia Social Responsibility}

The church in Zambia is recognised as one of the five key pillars of the nation, alongside the press, the judiciary, the legislature and the executive. This is a really great honour, with such great responsibility, and power, that it cannot be taken lightly. The church literally is an equal and critical partner with the government in the struggle to advance the wholeness of the Zambian people.

But the church is not the government, and must be careful not to lose its distinctiveness in its social engagement in order to contribute something unique - in the promotion of a hopeful vision of the nation. In the context of the 'nation of Zambia as a Christian nation', the church is well positioned to articulate a national vision of hope anchored in faith and in the reign of Christ, which should promote its unswerving commitment to the values of peace, justice, ethnic unity, human rights and the integrity of creation - all these issues are dominant in the biblical tradition. The challenge though is that the notion of a 'Christian nation' has been interpreted with monolithic fixity, which 'tends to ignore that, from a global perspective, there are strands within Christianity that adopt different interpretations of the bible and that, even in the Zambian

${ }^{2}$ For a detailed analysis of their perspectives, see Chammah J. Kaunda's (2016) article, 'The Public Religious Speech that Does Justice'. Also see, Adriaan S. van Klinken $(2011 ; 2013)$ on the heterosexist theology of Bishop Joshua Banda and his analysis of some of the recent debates on sexual minorities among Zambian Christians, respectively. 


\section{Chammah J. Kaunda \& Mutale M. Kaunda}

context, there are dissident voices' (Van Klinken 2014: 265). This normative interpretation is used to 'define the social and political character of Zambia as a Christian nation' (Van Klinken 2014: 265). As demonstrated below, the Church has potential to abuse the rights of minority groups and other religions.

Richard Vincent (2000: n.p.) rightly argues, 'The Christian has a special vision of the inherent dignity of every human person, a distinctive ideal of unity and peace among all people, a unique concern for freedom, a singular confidence in the value of suffering and sacrifice'. This means that in its social responsibility to promote human security, the church has a crucial responsibility to speak truth to power. The argument is, the church's witness and action are legitimatized by both divine authority and the vitality of faithfulness to its social action. It is well positioned to unceasingly maintain its prophetic voice, in matters of justice and human rights. In its very life and existence within society, the church is phenomenologically obligated not only to its congregants, but to every human being, to promote a safe haven for them. This means that even if the church disagrees with an individual's life orientation, it remains with a divine mandate to unconditionally love and to foster an attitude of compassionate concern for those that general society regard as different or even deviant.

Part of the vocation of the church is to engage the government in the search for ways of re-envisioning an alternative society, alternative politics and alternative ways of governance and being Zambians. Closely related to this is helping in transforming the national frame of reference and the way citizens treat one another as people created in the image of God. In this way, the church could help in establishing a firm social order grounded in justice and fairness, in which everyone has access to basic resources, that can help them pursue good life.

The need to make an ecumenical contribution in the realm of national public policies, and political agendas should be prioritized, over doctrine and practices in the church's witness and social action. It is clear from history that whenever the church in Zambia has stood as an ecumenical voice, radical socio-political transformations have resulted. It is also true that when the voice of the church is fragmented, it is utilised by politicians to advance their political interests. This has often muted the ecumenical voice of the ecumenical church. For instance, when President Lungu decided to reintroduce the National Guidance and Religious Affairs Ministry, the two mother bodies - CCZ and $\mathrm{ZCCB}$ - rejected the idea arguing that 'the Church derives its authority, mission 
and structure from God and this must not be confused with the temporal order of political governance' (Lusakatimes.com 2016).

Because Pentecostals dominated, and the EFZ welcomed the introduction of the ministry, as a means to promote Christian values and give more meaning to the declaration of Zambia as a Christian nation, President Lungu went ahead and reintroduced the ministry. This shows the need for the church to resist giving the impression that it is at the service of the government. Rather, one of the key aspects of the church's witness and social action is the continuous promotion of the ecumenical engagement with the government. The main question is, then, what should form the contours of the missioecclesia (the church's divine mandate of social responsibility) in the context of human security. The following contours expand on the position of two mother bodies' - CCZ and ZCCB - missio-ecclesia social praxes, in the context of human security in the nation.

The first social responsibility of the church is to function as an ecumenical body in its engagement with national issues and the government.

Second, this approach would help the church to continue to affirm the 'common denominator and our mutual rallying point between the Church and the State ... that we are both concerned about the common good and the wellbeing of God's people' (Lusakatimes.com 2016).

Third, it follows therefore, that the social responsibility of the church is also about engaging the State with a level of suspicion, in order to sustain the divine principles of God's option for the marginalised and excluded. This means, the affirmation of good initiatives by the State, but to simultaneously resist greediness, exploitation, corruption, human rights abuse, and the oppression of the marginalised. Even so, it is not just the state that the church should critique. The church is also responsible for self-critique. Self-critique is healthy for life-giving social engagement. This calls for the prophetic example, where the church resists and renounces the evils that are perpetuated within ecclesiastical cycles.

Fourth, it is through such understandings, that the church reaffirms itself over-and-over as deriving 'its authority, mission and structure from God, and this must not be confused with temporal order of political governance' (Lusakatimes.com 2016).

Fifth, if that is clearly understood, the church's self-identity becomes balanced with constructive resistance against political intimidation and clergy desire for social status in engaging in 'God-given mission of being the 


\section{Chammah J. Kaunda \& Mutale M. Kaunda}

conscience of the nation and exercising our prophetic ministry of calling for social justice following the example of our Founder, Jesus Christ' (Lusakatimes.com 2016).

Sixth, this also means that the church's social responsibility arises out of the need for recognition of the social function of all religious traditions. It discovers and rediscovers its social value and humanistic function through the socially engaged religious other. Therefore, in the church's search for effective social responsibility, Christian social conscious identity cannot be constructed 'by either ignoring the rest of the world's values and belief systems or acting as if only Christians were right or caring or concerned with justice, to show other religions are inferior' (Palmer 1991:55).

This also means, in a pluralistic society, constructing Christian nationalisms may not be a viable way for the church to engaged adequately in its social responsibility. Rather, it lies in the promotion of social responsibilities together with fellow members of the nation.

\section{Conclusion}

In this article, we traced the contribution of the church to both human securities and insecurities. It argues, from an African perspective, that African religious imaginations affirm the indivisibility of the supernatural and natural reality, without contradicting the humanistic function of religion in promoting holistic human security. Thus, the church, in many ways, has embraced this worldview by positioning itself as a religion of reconciliation and unification for various ethnic groups. It has adapted some values from the African religious past and introduced new ideals via education, health and love, that transcend ethnic diversity, to embrace all human beings as expression of the image of God.

However, we have also demonstrated that Christianity is also implicated in contributing to human insecurity for certain groups of people such as sexual minorities, through the perpetuation of homophobia, even gender injustices and inequalities. We have suggested that the church reposition itself as safe space, for welcoming strangers and embracing contradictions. This calls for other ways of being the church, that could help in re-envisioning alternative society, alternative politics and alternative ways of governance, and being Zambian. In other words, the church's social responsibility is to help conscientise the citizens in an ecumenical ethic of unconditional care which seeks to promote respect of the humanity of all, as people created in the image of God. 
Lastly, there can be little doubt that the faith communities in Zambia possess resources that can contribute to advance holistic human security, but this would require the church to redefine and reaffirm its missio-ecclesia mandate with ecumenical praxis.

\section{References}

Abass, Ademola (ed.) 2010. Protecting Human Security in Africa. Oxford: Oxford University Press.

https://doi.org/10.1093/acprof:oso/9780199578986.001.0001

Africa Analysis 1991. Africa Analysis: The Fortnightly Bulletin on Financial and Political Trends. Issues 113-137: 98.

Anderson, A.H. 2014. An Introduction to Pentecostalism: Global Charismatic Christianity. Cambridge: CUP.

https://doi.org/10.1017/CBO9781139524063

Banda, Joshua 2013. Engaging with the Community, The Fight against AIDS.

In Woolnough, B. (ed.): Good News from Africa: Community Transformation through the Church. Oxford: Regnum.

Behnassi, M. \& K. McGlade. Environmental Change and Human Security in Africa and the Middle East. Heidelberg, DE: Springer.

https://doi.org/10.1007/978-3-319-45648-5

Berger, Peter 1999. The Desecularization of the World: A Global Overview. In Berger, P. (ed.): The Desecularization of the World: Resurgent Religion and World Politics. Washington: Ethics and Public Policy Center.

Blog Admin 2010. 'Homosexuality Against African Norms - Anglicans'. http://www.southernafricalitigationcentre.org/2010/05/06/homosexuality -against-african-norms-anglicans/ (Accessed on 13 November 2015.)

Booth, N.S. 1978. Tradition and Community in African Journal of Religion in Africa 9, Fasc. 2: 81 - 94. https://doi.org/10.1163/157006678X00019

Calo Cesu Project 2017. 'Calo Cesu by United Gospel Artists' Reverbnation. https://www.reverbnation.com/calocesuproject/song/20266232-calocesu-by-united-gospel-artists (Accessed on 11 May 2017.)

Carmody, B. 2007. Catholic Church and State Relations in Zambian Education: A Contemporary Analysis. In Grace, G.R. \& J. O’Keefe (eds.); International Handbook of Catholic Education: Challenges for School Systems in the 21st Century. Netherlands: Springer. 
https://doi.org/10.1007/978-1-4020-5776-2 28

Carmody, B 2010. The Politics of Catholic Education in Zambia: 1964-2001.

Journal Paedagogica Historica 39,3: 286 - 303.

https://doi.org/10.1080/00309230307467

Chabal, P. \& J-P. Daloz 2006. Culture Troubles: Politics and the Interpretation of Meaning. University of Chicago Press.

Cornell, V.J. (ed.) 2007. Voices of Islam: Voices of the Spirit. Westport,

Connecticut and London: Praeger.

Dyrness, W. 1990. Learning about Theology from the Third World. Michigan: Zondervan.

Expanded Church Response (ECR) 2012. Mission, Vision, and Core Values. http://www.ecrtrust.org/about_us/mission-and-vision/

Gewald, J-B., M. Hinfelaar \& G. Macola (eds) 2008. One Zambia, Many

Histories. Towards a History of Post-colonial Zambia. Leiden: The Lembani Trust.

Gifford, P. 1998a. African Christianity: Its Public Role. London: Hurst \& Co. Gifford, P. 2015. Christianity, Development and Modernity in Africa. London: Hurst and Company.

https://doi.org/10.1093/acprof:oso/9780190495732.001.0001

Gordon, D.M. 2012. Invisible Agents: Spirits in a Central African History. Athens, OH: Ohio University Press.

Hall, R. 1964. Kaunda: Founder of Zambia. London: Longmans, Green \& Co. Hinfelaar, M. 2009. Legitimizing Powers: The Political Role of the Roman Catholic Church, 1972-1991. In Gewald, J-B., M. Hinfelaar \& Giacomo Macola (eds.): One Zambia, Many Histories-Towards a History of Postcolonial Zambia. Lusaka: Lembani Trust.

https://doi.org/10.1163/ej.9789004165946.i-304.45

Idowu, E. Bọlaji 1973. African Traditional Religion: A Definition. London. Jackson, W.J. 2005. Vijayanagara Voices: Exploring South Indian History and

Hindu Literature. Aldershot: Ashgate Publishing; Abington: Routledge. https://doi.org/10.4324/9781315548203

Katongole, E.M. 2009. Mirror to the Church: Resurrecting Faith after Genocide in Rwanda. Grand Rapids: Zondervan.

Kaunda, C.J. 2016a. The Public Religious Speech Acts that do Justice: Reclaiming the Narrative of Resistance in the Context of Heterosexism. JTSA 155, July Special Issue: 196 - 215.

Kaunda, C.J. 2016b. 'Neo-Prophetism, Gender and 'Anointed Condoms': 
Towards a Missio Spiritus of Just-Sex in the African Context of HIV. Alternation 23, 2: 64 - 88.

Kaunda, K 1962. Zambia Shall be Free: An Autobiography. New York: Frederick A. Praeger.

Lusakatimes.com. 2016. A Statement on The Position of the Council of Churches in Zambia (CCZ) And The Zambia Conference of Catholic Bishops (ZCCB) on the Proposed Creation of the Ministry of National Guidance and Religious Affairs'. Available at:

https://www.lusakatimes.com/2016/09/20/statement-position-councilchurches-zambia-ccz-zambia-conference-catholic-bishops-zccb-

proposed-creation-ministry-national-guidance-religious/

Lusakatimes.com. 2015. HH Accuse President Lungu of Inviting Witchdoctors to Help him Win 2016 Elections. Available at:

https://www.lusakatimes.com/2015/10/26/hh-accuse-president-lungu-ofinviting-witchdoctors-to-help-him-win-2016-elections/

M'fundisi, N. 2014. Pentecostal and Charismatic Spiritualities and Civic Engagement in Zambia (1964-2012). PhD, University of Birmingham.

Magesa, L. 1997. African Religion: The Moral Traditions of Abundant Life Maryknoll, New York: Orbis Books 1997.

Lutz, M. \& N.C. Kula 2008. Zambia: 'One Zambia, One Nation, Many Languages. Language and National Identity in Africa 291-313. Available: https://www.researchgate.net/publication/264824740_One_Zambia_One _Nation_Many_Languages

Mbiti, J. 1969. African Religions and Philosophy. London, Ibadan, Nairobi: Heinemann.

Mbiti, J.S. 1991. Introduction to African Religion. Second Edition. Portsmouth, N.H., and London: Heinemann Educational Books.

Mwape, R. 1991. Zambia Returns to God. National Mirror 18 - 24 November 1991: 5.

Olupona, J. 2014. African Religions: A Very Short Introduction. Oxford: Oxford University Press.

Palmer, M. 1991. What Should We Teach? Christians and Education in a Pluralist World. Geneva: WCC.

Phiri, I. 2001. Proclaiming Political Pluralism: Churches and Political Transitions in Africa. Westport, Conn.: Praeger.

Picard, L.A., T.F. Buss, B. Taylor, B Seybolt \& M.C. Lelei (eds.) 2015. Sustainable Development and Human Security in Africa: Governance as 
the Missing Link. Oakville: Apple Academic Press Inc.

https://doi.org/10.1201/b18455

Samson, C.M. 2012. Interrogating Human Security and Religion in

Guatemala'. In Wellman, J.K. \& C. Lombardi (eds.): New Religion and

Human Security: A Global Perspective. New York: OUP. Available at:

https://doi.org/10.1093/acprof:oso/9780199827732.003.0009

Shore, M. 2009. Religion and Conflict Resolution: Christianity and South

Africa's Truth and Reconciliation Commission. Basingstoke: Ashgate.

Sindima, H.J. 1990. Community of Life: Ecological Theology in African

Perspective. Available at:

http://www.religion-online.org/showarticle.asp?title=2327

Sindima, H.J. 1995. Africa's Agenda: Legacy of Liberalism and Colonialism in the Crisis of African Values. London: Greenwood Press.

Smith, J.H. \& R.I.J. Hackett (eds.) 2012. Displacing the State: Religion and Conflict in Neoliberal Africa. Indiana: University of Notre Dame Press.

Taylor, S.D. 2006. Culture and Customs of Zambia. Westport, Connecticut:

Greenwood Press.

Tembo, M.S. 2012. Satisfying Zambian Hunger for Culture: Social Change in the Global World. Bloomington, IN: Xlibris Corporation.

Ter Haar, G. \& S. Ellis 2006. The Role of Religion in Development: Towards

a New Relationship between the European Union and Africa. The European Journal of Development Research 18,3: 351 - 367.

https://doi.org/10.1080/09578810600893403

The Churches Health Association of Zambia (CHAZ) 2013. 'About Us'. http://www.chaz.org.zm/?q=about_us (Accessed on 16 May 2017.)

The Times of Zambia. Zambia: Catholics Deplore Homosexuality. 22 March, 2011. Available at:

http://www.southernafricalitigationcentre.org/2011/03/22/zambia-

catholics-deplore-homosexuality/ (Accessed 03 February 2016.)

Times of Zambia. Zambia: Channel Funds to Projects, Not Gay Rights, Donors Urged. 7 May, 2010. Available at:

http://www.southernafricalitigationcentre.org/2010/05/07/zambiachannel-funds-to-projects-not-gay-rights-donors-urged/

(Accessed on 13 November 2015.)

Van Klinken A.S. 2013. Gay Rights, the Devil and the End Times: Public Religion and the Enchantment of the Homosexuality Debate in Zambia. Religion 1 - 22. https://doi.org/10.1080/0048721X.2013.765631 
Van Klinken, A.S. 2014. Homosexuality, Politics and Pentecostal Nationalism in Zambia. Studies in World Christianity 20,3: 259 - 281. https://doi.org/10.3366/swc.2014.0095

Van Klinken, A.S. 2011. The Homosexual as the Antithesis of 'Biblical Manhood'? Heteronormativity and Masculinity Politics in Zambian Pentecostal Sermons. Journal of Gender and Religion in Africa 17,2: 129 - 142. Vincent, R.J. 2000. Models of the Church. Available at:

http://www.theocentric.com/ecclesiology/leadership/models_of the_chu rch.html (Accessed 16 May 2017.)

Waogaidu, J.C. 2014. Jesus Christ - Truly God and Truly Man: Towards a Systematic Dialogue between Christology in Africa and Pope Benedict XVI's Christological Conception. Münster: LIT-Verlag.

Weber, M. 2002. The Protestant Ethic and the Spirit of Capitalism. In Lambek, M. (ed.): A Reader in the Anthropology of Religion. Malden, MA: WileyBlackwell Publishing.

Westerlund, D. (ed.) 1996. Questioning the Secular State: The Worldwide Resurgence of Religion in Politics. London: Hurst \& Company.

Zambia Episcopal Conference (ZEC) 2016. Government Extols Church's Provision of Health Care in Zambia. Available at:

http://www.catholiczambia.org.zm/index.php/media-video-audio/news1/177-government -extols-church-s-provision-of-health-care-in-zambia, Zambia Episcopal Conference (ZEC) 2016. Health Department. Available at: http://www.catholiczambia.org.zm/index.php/2category/uncategorised/111-health-department (Accessed on 16 May 2017.)

Chammah J Kaunda (PhD) United Graduate School of Theology Yonsei University pastorchammah@gmail.com

Mutale Mulenga Kaunda (PhD) Independent Researcher Gender \& Religion mutalemkaunda@gmail.com 